As secretary in 1921-26 of the Education Section of the British Association Dr. Clarke did further work for the improvement of teaching methods ; she was also chairman of the committee on the teaching of general science in schools, with special reference to the teaching of biology.

Apart from her botanical work, Dr. Clarke had a wide knowledge, and love for, Old London, and only two years ago she founded the London Wanderers Club among old J.A.G.S. girls, herself acting as leader on periodical rambles, sparing no time and trouble in their successful organisation. The esteem in which she was held by her old students was marked last year by the foundation of a "Lilian Clarke" botany prize fund at James Allen's School, and no more fitting tribute to her memory could be raised than an extension of this fund for the further encouragement of the subject for which her life was spent. Her affection was fixed on Dulwich, and by her special request the first part of the funeral service was held in the old College Chapel, in the presence of the upper school and her friends and colleagues.

WiNifRed E. BRENCHLEY.

\section{Mr. R. J. Moss}

Throdgr the death on January 27 of $\mathrm{Mr}$. R. J. Moss at the age of eighty-seven years, the Irish scientific world has lost one of its last links with the brilliant period of which FitzGerald was the leading spirit. Moss was appointed keeper of the minerals and analyst to the Royal Dublin Society in 1875 , and registrar in 1878 , a position which he held until his retirement in 1921. He was the oldest member of the Royal Irish Academy, having been elected in 1874 .

Despite his onerous routine duties, Moss published many original papers, chiefly on chemical subjects. Among these may be mentioned those on cobalt chloride as a moisture test, on an improved method of determining the gases dissolved in water, and on the state in which helium exists in pitchblende. In the last he employed an ingenious method of extracting the helium by grinding the mineral in vacuo. He also investigated some archæological problems. His last paper, read before the Royal Irish Academy in 1926, deals with a chemical examination of some ancient metallurgical crucibles. From his analyses he arrived at important conclusions as to the metallurgical knowledge of the ancient Irish.

Moss, however, like so many scientific men of his period, did not restrict his work entirely to one branch of science. His earliest work, carried out in collaboration with H. N. Draper, dealt with the photoconductivity of the allotropic forms of selenium. He published papers on the spheroidal state and in 1896 investigated the effect of X-rays on the combination of hydrogen and chlorine and on the fluorescence of various salts.

It is perhaps for his work in the foundation of the Irish Radium Institute that he will be longest remembered. When Joly first proposed his method of using radon in fine glass capillaries for therapeutic purposes, Moss designed and constructed the requisite apparatus. In this his skill as a glassblower and his knowledge of handling small quantities of the rare gases were a great asset. The original apparatus was used for many years at the Institute. During the War he, and his two assistants Messrs. Stone and Deane, carried out all the work of the Institute, and large quantities of radon were supplied to various military hospitals, mainly for the treatment of wound scars.

To those who knew Moss only in his later years, one of his most striking characteristics was the extreme ease with which he carried their burden. To the last he was a valued member of the Irish Radium Institute Committee and a regular attendant at scientific meetings. Of him, I think, we can use, in its best sense, the saying: He, whom the gods love, dies young.

$$
\text { J. H. J. Poole. }
$$

\section{Prof. T. Eric Peet}

We regret to record the death on February 22 at the age of fifty-two years of Thomas Eric Peet, reader in Egyptology in the University of Oxford.

Eric Peet was educated at Merchant Taylors' School, of which in later life he became a governor, and at Queen's College, Oxford, where he was Jodrell scholar and graduated with second class honours in Classical Moderations and Literce Humaniores. In 1906 he was awarded a Craven fellowship and entered the British School of Archæology in Rome, later holding the Pelham studentship. The results of his researches were published in 1909 in "The Stone and Bronze Ages in Italy and Sicily", a book which is still recognised as a standard authority.

Peet then turned his attention to Egyptology; and this remained his principal occupation for the rest of his life. He excarated in Egypt at Abydos, at first under Prof. Garstang and then as assistant to Prof. Naville, on behalf of the Egypt Exploration Fund, collaborating in vols. 1-2 of the valuable memoirs on the cemeteries of that site. He also collaborated in a publication on the inscriptions of Sinai. A work entitled "Rough Stone Monuments and their Builders" appeared in 1912. In the following year Peet was appointed lecturer in Egyptology in the University of Manchester.

After the War, in which Peet served with the King's (Liverpool) Regiment in Salonika and France, he resumed excavation in Egypt on behalf of the Fund at El-Amarna, publishing "The City of Akhenaton", vol. 1 in 1923. His "Egypt and the Old Testament", a book of more general appeal than his other works, had appeared in 1922, and in the meantime he had also devoted attention to the study of papyri, more particularly those of a mathematical character, the result appearing in publications issued from 1920 onwards, dealing with the Rhind, Mayer and other papyri. On Prof. P. E. Newberry's retirement from the 
Brunton professorship in the University of Liverpool in 1923, Peet was appointed to succeed him, and in the same year was elected Laycock student of Egyptology of Worcester College, Oxford. From that time onward Peet ceased to take an active part in field work, but devoted himself to teaching and research, also editing the Annals of Archoeology and Anthropology (Liverpool) and the Journal of the Egypt Exploration Society. His "The Egyptian Dynasty" appeared in 1930 and his Schweich Lectures, on "Comparative Study of the Literatures of Egypt, Palestine and Mesopotamia", in 1931. On the retirement of Prof. F. Ll. Griffith from the chair of Egyptology at Oxford last year, Peet was appointed as reader ; being also elected to a fellowship by his own college.

At the very outset of his career, Peet was recognised as a brilliant archæologist, and at no time did his performance fall below expectation.
WE regret to announce the following deaths:

Dr. F. A. Bather, F.R.S., formerly keeper of the Department of Geology, British Museum (Natural History), on March 20, aged seventy-one years.

Prof. Davidson Black, F.R.S., professor of anatomy in Peiping Union Medical College and honorary director of the Cenozoic Research Laboratory, National Geological Survey of China, on March 15, aged forty-nine years.

Prof. F. L1. Griffith, emeritus professor of Egyptology in the University of Oxford, on March 14, aged seventy-one years.

Dr. Walter Rosenhain, F.R.S., formerly superintendent of the Department of Metallurgy and Metallurgical Chemistry in the National Physical Laboratory, on March 17, aged fifty-eight years.

\section{News and Views}

\section{Liquid Crystals}

We are publishing as a special supplement this week an account by Sir William Bragg, director of the laboratories of the Royal Institution, of those substances which in Great Britain are usually called 'liquid crystals": Their very striking appearances on the microscope stage are fairly well known; but this is the first time that a coherent story has been made of the optical principles by which their characteristic behaviour is exhibited. The authors of even the most modern books on opties have not given this matter their attention; and until recently only superficial notice had been taken in Great Britain of this class of substance. The examination and explanation of their behaviour links them on one hand to the large class of oriented liquid films, and suggests on the other hand that more regular structure which X-ray analysis is daily revealing to us in so many directions. By means of new photographs, diagrams and drawings of models, Sir William Bragg has with appealing directness given us a statement of the problems which these bodies have yielded. The optical behaviour of the main groups is thus seen to be related to a varying degree of regularity of arrangement while in the mobile phase. Sir William's article, which gives a clear picture of the subject without going greatly into detail, will provide a stimulus to the growing interest which Friedel's 'mesomorphs' are attracting among physicists and others in Great Britain.

\section{Sir Robert Greig}

Sir Robert Greig, Secretary of the Department of Agriculture for Scotland, is about to retire from that position, as he attains his sixtieth year on March 23. He has only held the post for about five years, but that has been long enough for him to prove himself an excellent chief who has backed all scientific development in his Department. After leaving the University of Edinburgh, Sir Robert was for a time a ranch manager in north-west Canada. After returning to England he was for two years lecturer at the Cheshire Agricultural College, passing on for four years to the Durham College of Science. In 1903-10 he was the Fordyce lecturer in agriculture at the University of Aberdeen. In 1911 he returned south to become staff inspector in agriculture at the Board of Education, but not for long, for in the same year he became a commissioner at the Board of Agriculture, Scotland, of which body he was chairman in 1921-28. The combination of technical knowledge and administrative ability exemplified by Sir Robert goes far to explain his success ; and general regret is expressed at his impending retirement.

\section{Technical Officers and Administrative Posts}

ON or about the same date that Sir Robert Greig retires, one of the four assistant secretaries of the Scottish Agriculture Department is also due to retire, in the person of Mr. H. M. Conacher. It may almost be assumed that their successors will be Scotsmen, or there would be 'wigs on the green' at Westminster. It is to be hoped also that on this occasion full consideration will be given to the claims of technical officers in Government departments to be selected for these posts, instead of assuming, as is usually done, that they cannot be capable administrators. The functions of the Scottish Department of Agriculture are of a character which render technical knowledge and experience, in addition to administrative ability, highly desirable qualifications for the controlling posts. The Department's work is largely concerned with the scientific development of agriculture, the organisation of agricultural education, and the carrying out of schemes of land settlement. For these purposes it employs a variety of technical experts, and it is not too much to ask that senior members of these technical staffs should definitely be brought under review in the filling of the impending vacancies in the controlling posts. 